\title{
Review
}

\section{Cardiovascular causes of dementia}

\section{Demansın kardiyovasküler sebepleri}

\author{
Fulya Avci DEMIR* $\square$
}

Elmali State Hospital, Department of Cardiology, Antalya/TURKEY

\begin{abstract}
Dementia, as a geriatric syndrome, is an increasing concern as the ageing population grows worldwide and it is more common due to enhanced diagnostic tools. The incidence of dementia is low before 75 years of age and increases exponentially with age, even in the oldest age groups. Dementia and heart health are in close relationship. Coronary artery disease risk factors, atrial fibrillation, heart failure and some medications given for cardiovascular diseases can lead to dementia via systemic effects and also worsen dementia. Prevention and treatment of cardiovascular disease in early ages and the choice of medications may affect prognosis of dementia as well as primary cardiovascular disease.
\end{abstract}

Keywords: Cardiovascular; dementia; elderly

\section{Öz}

Geriatrik bir sendrom olan demans, dünya çapında yaşlı popülasyondaki artış ve gelişmiş tanı araçları sebebiyle giderek artan bir sağlık problemidir. Demans insidansı 75 yaşından önce düşüktür ve ileri yaş gruplarında bile yaşla birlikte katlanarak artmaktadır. Demans ve kalp sağlığı yakın ilişki içindedir. Koroner arter hastalığı risk faktörleri, atriyal fibrilasyon, kalp yetmezliği ve kardiyovasküler hastalıklar için verilen bazı ilaçlar sistemik etkiler ile demansa neden olabilir ve demansı kötüleştirebilir. Erken yaşta kardiyovasküler hastalıkların önlenmesi ve tedavisi için uygun ilaç seçimi primer kardiyovasküler hastalığın yanı sıra demans prognozunu etkileyebilir.

Anahtar kelimeler: Kardiyovasküler; demans; yaşlı 


\section{Introduction}

Dementia, as a geriatric syndrome, is an overall term for a set of symptoms that are caused by disorders affecting the brain. Symptoms may include memory loss and difficulties with thinking, problem-solving or language, severe enough to reduce a person's ability to perform everyday activities. A person with dementia may also experience changes in mood or behavior[1]. Dementia is not a specific disease. Many diseases can cause dementia, including Alzheimer's disease, vascular dementia (due to strokes), Lewy Body disease, head trauma, fronto-temporal dementia, Creutzfeldt-Jakob disease, Parkinson's disease, and Huntington's disease. These conditions can have similar and overlapping symptoms. Some treatable conditions can produce symptoms similar to dementia, for example, vitamin deficiencies, thyroid disease, sleep disorders, or mental illness. It is therefore important to arrange for a full medical assessment as early as possible[2]. Dementia is an increasing concern as the ageing population grows worldwide and it is more common due to enhanced diagnostic tools. The incidence of dementia is low before 75 years of age and increases exponentially with age, even in the oldest age groups[3]. Amyloid accumulation eventually leading to $A D$ neurodegeneration starts decades before clinical symptoms emerge like atherosclerosis process starts early in adulthood[4].

Vascular risk factors associated with dementia and cognitive impairment include hypertension, hypercholesterolemia, diabetes, obesity and smoking. It is controversial whether or not some of these factors have a direct impact on the development of the specific neuropathological lesions in Alzheimer's disease(AD) or if the effects are mediated by cerebrovascular disease or both. Importantly, these vascular risk factors are modifiable, representing an opportunity for interventions that could prevent or postpone the onset of dementia with a possible major effect on public health[5,6].

\section{Hypertension}

Arterial hypertension is an important risk factor for the development of cerebrovascular events. The basal measurements of the middle age group were found to be at risk for the development of vascular dementia in the longterm follow-up of individuals who were compatible with hypertension[7,8]. Studies have shown that high systolic blood pressure is a significant risk factor for the development of vascular dementia[8,9].In Honolulu Asia Aging Study patients were followed up for 25 years and at the end of this study it is found that $27 \%$ of dementia syndromes depends on untreated hypertension[9]. In another study, including 1385 patients with mild cognitive disorder, after 2 years of follow-up, hypertensive patients with high systolic blood pressure were found to have faster cognitive deterioration and a significant deterioration in visual-motor abilities[10]. In addition to the fact that middle age hypertension is known as a definite risk factor, the results of late age hypertension studies on cognitive functions are contradictory. Optimal blood pressure value for brain functioning is important. Just like high blood pressure, too low arterial blood pressure or inappropriate treatment can disrupt the cognitive functions by disrupting brain blood flow[11]. In addition, rapid changes in blood pressure may affect cerebral blood supply. Hippocampus, the entorhinal cortex and the prefrontal cortex are the brain regions affected most by perfusion changes and also responsible for memory and executive functions $[12,13]$. There are also studies showing that increased pulse pressure is a risk factor for cognitive impairment and Alzheimer type dementia development[14].

Effects of hypertension treatment on dementia is also important. AHA/ASA recommends treating high blood pressure in patients who had a stroke before to prevent dementia occurance. The same level of certainty and suggestion is not relevant for the treatment of hypertension and dementia after 80 years of age[15,16].

In patients $\geq 80$ years of age hypertension treatment starting threshold is $\geq 160 \mathrm{mmHg}$ and treatment target is $140-150$ $\mathrm{mmHg}$. In the elderly all hypertension drugs are recommended, but diuretics and calcium antagonists are preferred more frequently in isolated systolic hypertension[17].

If the average of systolic blood pressure is $\geq 130 \mathrm{mmHg}$ treatment is recommended for the elderly (> 65 years) who are able to take care of themselves and the treatment target is $<130 \mathrm{mmHg}$ [18]. Large population studies with longer follow-up period are needed to understand the effects of antihypertensive agents on cognition.

\section{Hyperlipidemia}

Atherosclerosis has an important role in the development of coronary artery disease(CAD) and dementia. Often, dementia shares the same etiologic factors as CAD. In Cardiovascular health study, patients with CAD had a higher incidence of dementia[19]. Cytotoxicity and inflammation, which are also related with hypercholesterolemia has an important role in the pathophysiology of dementia. Therefore, uncontrolled cholesterol load is a triggering factor in the brain atrophy. It is shown that middle age cholesterol is an independent risk factor for dementia development[20]. In autopsy studies , 
it was observed that high LDL levels in early age significantly increased amyloid load[21] .It is the focus of interest that statin use will be associated with dementia,especially Alzheimer type dementia.Since older people usually have co-morbidities and their pharmacokinetics are different, lipid-lowering therapies should be initiated with low dose and dose titrations should be performed more carefully to achieve lipid therapy targets[22].

\section{Heart Failure}

It was understood that heart failure caused cognitive impairment and cognitive impairment progressed as the severity of the disease increased[23,24].Mechanisms that explain the pathology and destruction are reduced neuron oxygenation,increased oxidative stress, and lack of amyloid removal. Decreased left ventricular ejection fraction and cardiac output has been associated with abnormal brain aging and impaired cognition[25,26]. It has been shown that cerebrospinal fluid decreases in patients with heart failure and this increases the frequency of cognitive impairment[27]. There is also relationship between heart failure medications and cognitive functions. Diüretic therapy which is one of the cornerstones of the treatment may effect electrolyte balance and hyponatremia may cause cognitive deterioration[28]. The correction of hyponatremia should also be managed extremely careful. Because if hyponatremia is remedied quickly,central pontine can cause irreversible brain damage by causing myelolinization.

Angiotensin 2 receptor blockers, which are frequently used in the treatment of heart failure has neuroprotective effects as a neuromuscular blocker[29].

For this reason, the side effects and protective effects of the drugs should be taken into consideration,the benefit and loss balance should be calculated and than medication should be decided.It may be better to follow old patients with heart failure in a multidisciplinary geriatric clinic including ideal rehabilitation programs.

\section{Atrial Fibrillation}

There is growing evidence that atrial fibrillation (AF) is associated with higher risk of dementia and Alzheimer's disease[30], raising the possibility that interventions targeting AF might prevent or delay some cases of dementia.

It is very wellknown that atrial fibrillation causes embolic strokes and silent cerebral emboli, also it deteriorates cognitive functions by causing cerebral hypoperfusion.Possible mechanisms include embolic strokes [31], silent cerebral emboli [32], and cerebralhypoperfusion [33,34]. It is not known whether AF contributes to AD-associated neuropathologic changes such as neurofibrillary tangles and neuritic plaques. In a study supported by postmortem examinations, infarct areas in the brain were observed to be more frequent in patients with atrial fibrillation. It has been demonstrated in large meta-analyzes that $A F$ is an independent risk factor for dementia except causing stroke[35,36].

As a result, dementia and heart health are in close relationship. Cardiovascular disease, another common health problem among eldery people can lead to dementia via systemic effects and also worsen dementia.Prevention and treatment of cardiovascular disease in early ages and the choice of medications may affect prognosis of dementia as well as primary cardiovascular disease[5].

\section{Declaration of conflict of interest}

The authors received no financial support for the research and/or authorship of this article. There is no conflict of interest.

\section{References}

1. Daviglus ML, Bell CC, Berrettini W et al. NIH state-of-the science conference statement: preventing Alzhemier's disease and cognitive decline. NIH Consens State Sci Statements. 2010; 27: 1-27.

2. KIzIl ET. Other Dementias. J Psychiatry-Special Topics 2017; 10: 37-43

3. Fratiglioni L, Viitanen M, von Strauss E, Tontodonati V, Herlitz A, Winblad B. Very old women at highest risk of dementia and Alzheimer's disease: incidence data from the Kungsholmen project, Stockholm. Neurology1997; 48: 132-38.

4. Rowe CC, Ellis KA, Rimajova M, Bourgeat $P$ et al. Amyloid imaging results from the Australian Imaging, Biomarkers and Lifestyle (AIBL) study of aging. Neurobiol Aging 2010; 31: 1275-83.

5. Whitmer RA, Sidney S, Selby J, Johnston SC, Yaffe K. Midlife cardiovascular risk factors and risk of dementia in late life. Neurology 2005; 64: 277-81.

6. Kivipelto M, Helkala EL, Laakso MP et al. Midlife vascular risk factors and Alzheimer's disease in later life: longitudinal, population based study. BMJ 2001; 322: 1447-51.

7. Love S, Miners JS. Cerebrovascular disease in aging and Alzhemier's disease. Acta Neuropathol 2016; 131: 645-58.

8. Rönnemaa E, Zethelius B, Lannfelt L, Kilander L.Vascular risk factors and dementia: 40 year follow-up of a population-based cohort. Dement Geriatr Cogn Disord 2011; 31:460-66.

9. Launer LJ, Masaki K, Petrovitch H, Foley D, Havlik RJ. The association between midlife blood pressure levels and late-life cognitive function. The Honolulu Asia Aging Study. JAMA 1995; 274: 1846-51. 
10. Goldenstein FC, Allan I. Levery, Steenland NK. High Blood Pressure and Cognitive Decline in Mild Cognitive Impairment. J Am Geriatr Soc 2013; 61: 67-73.

11. Mahoney JR, Verghese J, Goldin Y, Lipton R, Holtzer R. Alerting, orienting, and executive attention in older adults. J.Int Neuropsychol Soc 2010; 16: 877-89.

12. Gasecki D, Kwarciany M, Nyka W, Narkiewic K. Hypertension, Brain Damage and Cognitive Decline. Curr Hypertens Rep 2013; 15: 547-58.

13. Raz N, Rodrigue KM, Kennedy KM, Acker JD. Vascular health and longitudinal changes in brain and cognition in middle-aged and older adults. Neuropsychology 2007; 21: 149-57.

14. Waldenstein SR, Rice SC, Thayer JF, Najjar SS, Scuteri A, Zonderman $\mathrm{AB}$. Pulse pressure and pulse wave velocity are related to cognitive decline in the Baltimore Longitudinal Study of Aging. Hypertension 2008; 51: 99-104

15. Gorelick PB, Scuteri A, Black SE et al.Vascular contributions to cognitive impairment and dementia: a statement for healthcare professionals from the AHA/ASA. Stroke 2011; 42: 2672-713.

16. Jennings JR, Mendelson DN, Muldoon MF et al. Regional grey matter shrinks in hypertensive individuals despite successful lowering of blood pressure. J Hum Hypertens 2012; 26: 295-305.

17. Williams B, Mancia G, Spiering W et al. 2018 ESC/ESH Guidelines for the management of arterial hypertension. European Heart Journal 2018; 39: 3021-104

18. 18. Whelton PK, Carey RM, Aronow WS et al. 2017 ACC/AHA/ AAPA/ABC/ACPM/AGS/APhA/ASH/ASPC/NMA/PCNA Guideline for the Prevention, Detection, Evaluation, and Management of High Blood Pressure in Adults. Hypertension. 2018; 138: 426-83

19. Newman $A B$, Fitzpatrick $A L$, Lopez $O$ et al. Dementia and Alzhemier's disease incidence in relationship to cardiovascular disease in the Cardiovascular Health Study cohort. J Am Geriatr Soc 2005; 53: 1101-107.

20. Eichner JE, Dunn ST, Perveen G, Thompson DM, Stewart KE, Stroehla BC. Apolipoprotein-E polymorphism and cardiovascular disease: a HuGE review. Am J Epidemiol 2002; 155: 487-95.

21. Pappolla MA, Bryant-Thomas TK, Herbert D et al. Mild hypercholesterolemia is an early risk factor for the development of Alzhemier amyloid pathology. Neurology 2003; 6: 199-205.

22. Catapano AL,Graham I, Backer GD et al. 2016 ESC/EAS Guidelines for the Management of Dyslipidaemias. European Heart Journal 2016; 37: 2999-3058

23. Azad N, Lemay G. Management of chronic heart failure in the older population.Journal of Geriatric Cardiology 2014; 11: 329-37
24. Cermakova P, Eriksdotter M, Lund LH, Winblad B, Religa P, Religa D. Heart failure and Alzhemier's disease. Journal of Internal Medicine 2015; 277; 406-25.

25. Jefferson AL. Cardiac output as a potencial risk factor for abnormal brain aging. J Alzhei mers Dis 2010; 20: 813-21

26. Jefferson AL, Himali JJ, Au R et al. Relation of left ventricular ejection fractionto cognitive aging (from the Framingham Heart Study) Am J Cardiol 2011; 108: 1346-51.

27. Paulson OB, Jarden JO, Godtfredsen J,Vorstrup S. Cerebral blood flow in patients with congestive heart failure treated with captopril. Am J Med 1984; 76: 91-95

28. Tulner LR, Van Campen JP, Kuper IM et al. Reasons for undertreatment with oral anticoagulants in frail geriatric outpatients with atrial fibrillation: a prospective, descriptive study. Drugs Aging 2010; 27: 39-50.

29. Soto ME, van Kan GA, Nourhashemi F etal. Anjiotensin-converting enzyme inhibitors and Alzhemier's disease progression in older adults: results from the Reseau sur laMaladie d'Alzheimer Francais Cohort. J Am Geriatr Soc 2013; 61: 1482-88.

30. Kwok CS, Loke YK, Hale R, Potter JF, Myint PK. Atrial fibrillation and incidence of dementia: a systematic review and metaanalysis. Neurology 2011; 76: 914-22.

31. Schneider JA, Wilson RS, Cochran EJ et al. Relation of cerebral infarctions to dementia and cognitive function in older persons. Neurology 2003; 60: 1082-1088.

32. Ezekowitz MD, James KE, Nazarian SM et al. Silent cerebral infarction in patients with nonrheumatic atrial fibrillation. The Veterans Affairs Stroke Prevention in Nonrheumatic Atrial Fibrillation Investigators. Circulation 1995; 92: 2178-82

33. Lavy S, Stern S, Melamed E, Cooper G, Keren A, Levy P. Effect of chronic atrial fibrillation on regional cerebral blood flow. Stroke 1980; 11: 35-38

34. Petersen P, Kastrup J, Videbaek R, Boysen G. Cerebral blood flow before and after cardioversion of atrial fibrillation. J Cereb Blood Flow Metab 1989; 9: 422-25

35. Dublin S, Anderson ML, Hecbert SR et al. Neuropathologic Changes Associated With Atrial Fibrillation in a PopulationBased Autopsy Cohort. J Gerontol A Biol Sci Med Sci 2014; 69: 609-15.

36. Poggesi A, Inzitari D, Pantoni L. Atrial fibrillation and cognition epidemiological data and possible mechanisms. Stroke 2015; 46: 3316-21 